Romanelli, R. C. and A. M. Sebbenn (2004): Parâmetros genéticos e ganhos na seleção para produção de resina em Pinus elliottii var. elliottii, no Sul do Estado de São Paulo. Rev. do Inst. Flor. 16: 11-23.

Sebbenn, A. M., C. L. S. Pires, L. Stork and A. Custodio FilHo (1994): Variação genética em progênies de meiosirmãos de Pinus caribaea Mor. var. bahamensis Bar. et. Gol. na Região de Bebedouro-SP. Rev. do Inst. Flor. 6: 63-73.

S.A.S. (1989): Institute Inc. SAS Procedures Guide. Version 8 (TSMO). SAS Institute Inc. Cary, N.C., 27513, USA.

WRIGHT, J. W. (1978): A simplified design for combined provenance and progeny testing. Silvae Genetica 27: 68-70.
ZhenG, Y. O. and R. EnNos (1997): Changes in mating system of populations of Pinus caribaea Morelet var. caribaea under domestications. Forest Genetics 4: 209-215.

ZHENG, Y. O. and R. ENNOS (1999): Genetic variability and structure of natural and domesticated populations of caribaean pine (Pinus caribaea Morelet). Theor. Appl. Genet. 98: 765-771.

Zheng, Y. O., R. EnNos and H. R. WANG (1994): Provenance variation and genetic parameters in a trial of Pinus caribaea Morelet var. bahamensis and Golf. Forest Genetics 1: 165-174.

\title{
Short Note: Root Restriction Hindered Early Allometric Differentiation Between Seedlings of Two Provenances of Canary Island Pine
}

\author{
By J. Climent ${ }^{1),}{ }^{*}$, J. Alonso ${ }^{2)}$ and L. GiL ${ }^{2)}$
}

(Received $5^{\text {th }}$ December 2006)

\begin{abstract}
Based on the optimal partitioning theory, the comparative assessment of seedling allometry is a common task in retrospective genetic tests and early testing of forest reproductive material. Our hypothesis was that root restriction imposed by the container might hinder or rule out genetic differences in biomass allocation. We grew seedlings of two contrasted provenances of Canary Islands pine in mini-rhizotrons, 60 and $90 \mathrm{~cm}$ deep, and alternatively in standard bottom-open $200 \mathrm{cc}$ forest containers. In the mini-rhizotrons, plants from the drier provenance allocated more biomass to roots, especially to the tap root and invested less in needles, both in a biomass and leaf area basis, and this morphological divergence increased between two harvests, undertaken at 57 and 115 days after planting. By contrast, confirming our hypothesis, at the 115 days harvest, the plants grown in standard containers did not exhibited significant differences between provenances for Leaf Mass Fraction, Root Mass Fraction and Leaf Area Ratio. We conclude that the physical constraint for root development imposed by small containers increases the probability of dismissing the genetic effect in biomass alloca-

1) Unidad de Genética Forestal - INIA. Ctra. de la Coruña Km 7.5, 28040 Madrid. España.

2) Unidad Docente de Anatomía, Fisiología y Genética Forestales, ETSIM, UPM, Ciudad Universitaria s/n, 28040 Madrid. España.

*) Corresponding author: J. Climent, Unidad de Genética Forestal, Instituto Nacional de Investigación y Tecnología Agraria y Alimentaria (INIA) , Ctra. de la Coruña $\mathrm{Km} \mathrm{7.5,} \mathrm{28040-}$ Madrid (ESP). Tel.: +34(91) 3476862 . Fax.: +34(91) 3476767. E-mail: climent@inia.es.
\end{abstract}

tion when assessing forest reproductive materials at the short term, even when the whole plant growth (total dry weight) might be unaffected.

Key words: Mini-rhizotrons, root architecture, container, biomass allocation, ontogeny.

\section{Introduction}

Seedling allometry and root architecture are widely recognised as traits of adaptive and evolutionary significance in plants (NIKLAS and ENQUIST, 2002; NIKLAS, 2004; KeRKHOFF and EnqUisT, 2006) and closely related to plant field performance (WANG and SмIтH, 2004). Root conformation is a key aspect in plant adaptation to different and variable soil and climate, allowing the capture of water and nutrients at different levels in the soil; in fact rooting depth has been postulated to correspond to adaptive strategies across biomes at the global level (GLIMSKAR, 2000; GUERRERO-CAMPO and FitTer, 2001).

In forest species, determining seedling allometry and root architecture are common tasks in retrospective genetic tests and early testing of reproductive material (planting stock quality) (APHALO and RIKALA, 2003; BEAULIEU et al., 2004). However, the available information on whole plant allometry and root traits in forest species is insufficient (DANJON et al., 1999; PAZ, 2003; DANJON et al., 2005), especially considering intra-specific variation (RETZLAFF et al., 2001). On the other hand, the effect of container size and the subsequent mechanical restriction to root growth has been widely studied in a plethora of forest trees and horticultural plants (see for 
example FERREe et al., 1992; BEESON, 1993; NESMith and Duval, 1998, Aphalo and Rikala, 2003). While some works support that studies using pots may successfully mimic natural conditions in herbaceous plants and woody shrubs (BERNTSON et al., 1993), the allometric differences and field performances of bare-root and containerized seedlings are frequent causes of concern amongst forest managers (THIFFAULT, 2004). On the other hand, most widely-used forest containers produce continuous auto-pruning of the roots, conducive to a denser and more fibrous root system, and hence to more numerous new root tips favouring plant establishment in the field (RUNE, 2003) but possibly altering the natural patterns of biomass investment.

While many pines are shallow-rooting species, some species living habitats with deep, loose soils seem to have adapted to drought and fires through the development of conspicuous taproots (KEELEY and ZEDLER, 1998). The endemic Canary Islands pine (Pinus canariensis $\mathrm{Chr}$ Sm ex DC), a well known tree used both for ornamental and forest purposes in Mediterranean Climate Zones is an interesting species regarding root traits. We have seen taproots about $6 \mathrm{~m}$-deep in its volcanic natural habitat (Figure 1), probably related to its life-history: tall, long-lived trees highly resistant to fire and other disturbances (CLIMENT et al., 2004). On the other hand, variable combinations of soil texture (from very loose volcanic sands to heavy clayey soils), rainfall (from less than 300 to more than $1000 \mathrm{~mm}$ per year) and slope steepness, have conduced to sharp differences in

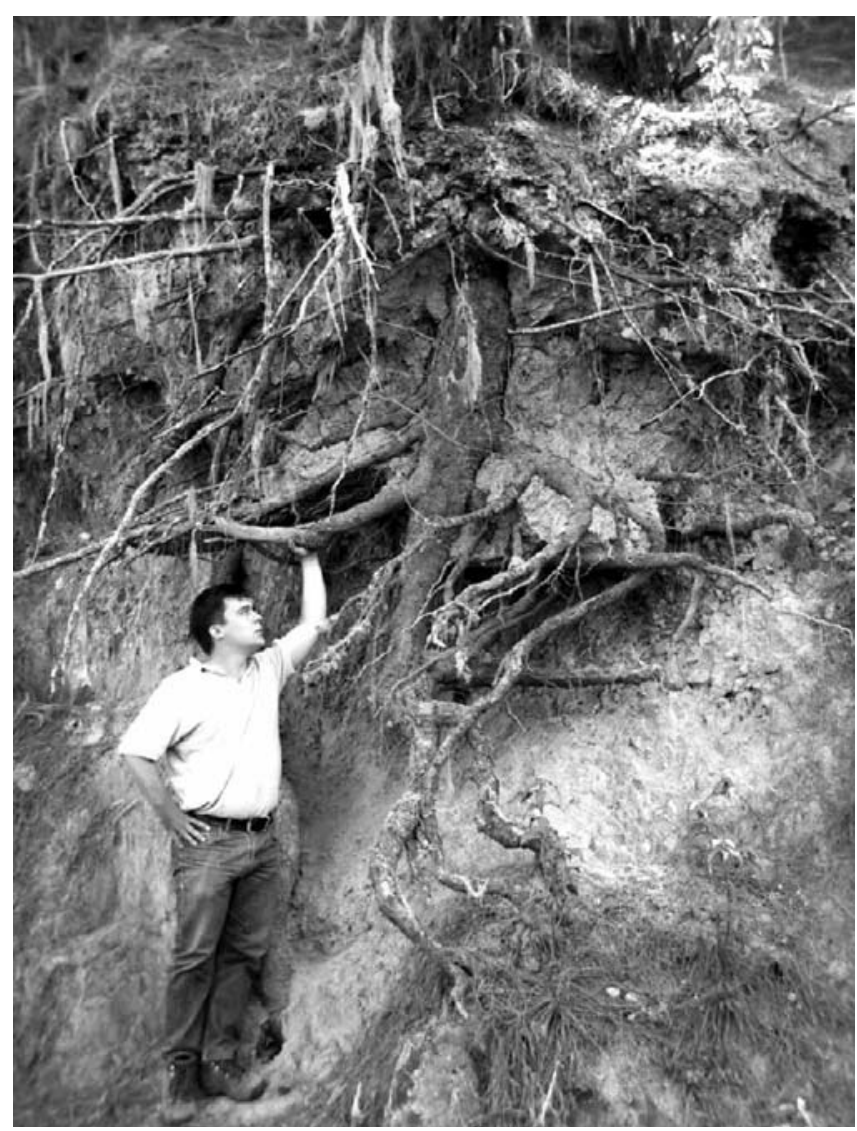

Figure 1. - Taproot of a 45 years-old Canary Island pine at the edge of a forest track in La Orotava (North of Tenerife). water availabilities across the species' natural distribution (BLANCO et al., 1989). These ecological differences, together with low gene flow among populations both between and within islands (GOMEZ et al., 2003) are coherent to the adaptive variation observed in field provenance trials (Climent et al., 2002; Climent et al., 2006).

To test the hypothesis that genetically-based differences in biomass allocation might not be expressed under physical constraints for root development due to the container, we carried out a greenhouse experiment comparing two contrasting provenances of Pinus canariensis cultivated in mini-rhizotrons and standard forest containers.

\section{Material and Methods}

We used seeds from two provenances of Canary Island pine: Vilaflor $(V)$ from Tenerife and Inagua-Pajonales $(P)$ from Gran Canaria, both of well documented autochthonous origin (CEBALlos and ORTUÑO, 1951) and widely used in afforestation. Both provenances differ in altitude, mean annual rainfall, mean annual temperature and potential evapo-transpiration, being $P$ from a warmer and drier climate (Table 1). Especially, an indirect site quality index based on the mean pine sapwood area per hectare, Gs (CLIMENT et al., 2004) shows sharp differences between both provenances, with the lower values corresponding to the more limiting conditions of $P$ provenance. To ensure a reasonable sampling of the provenances, we used random sample taken form an equilibrated mix of seeds collected from 25 to 30 openpollinated, non-neighbour individuals per provenance.

The trial was entirely conducted in a non-heated glass greenhouse under full light conditions. We used plastic, $\mathrm{D}$-shaped mini-rhizotrons $16 \mathrm{~cm}$ wide, $90 \mathrm{~cm}\left(\mathrm{R}_{90}\right)$ and $60 \mathrm{~cm}\left(\mathrm{R}_{60}\right)$ deep and $200 \mathrm{cc}, 18 \mathrm{~cm}$ deep forest plastic containers (Forest-Pot ${ }^{\circledR}$, further referred to as $\mathrm{C}_{200}$ ). Plants of the two provenances were randomly assigned to each container type, 6 plants per provenance in $R_{90}$ and $\mathrm{C}_{200}$, and 4 plants per provenance in $\mathrm{R}_{60}$. The total volume of the rhizotrons was $7.0 \mathrm{l}$ for $\mathrm{R}_{90}$ and $4.2 \mathrm{l}$ for $R_{60}$. The rhizotrons were arranged with a $30^{\circ}$ inclination from the vertical to facilitate root growth close to the flat, removable side (Figure 2). The growing media consisted of a mix of peat and vermiculite (1:2) plus $3 \mathrm{~g} / \mathrm{l}$ of slow-releasing Osmocote ${ }^{\circledR}$ fertiliser. To ensure the same water content in all containers we checked this parameter weekly with a Time Domain Reflectometer (TDR), measuring both upper $(10 \mathrm{~cm})$ and bottom layers. Watering was added proportionally to each container to keep mean water content between $35 \%$ and $40 \%$ in volume. Styrophoam panels attached around each mini-rhizotron were used to minimize the differences in temperature of the rooting media between container types.

Seeds were previously weighted to control maternal effects, and then germinated in a chamber. Three germinated seeds were planted in each container (this moment taken as Julian Day, [JD] 0), two of which were eliminated when cotyledons were fully expanded. With this process, we ensured that the remnant seedlings were in the same developmental stage. Nevertheless, 
Table 1. - Climate characteristics and site quality index $(\mathrm{Gs})$ for the two provenances analysed. MAP, mean annual precipitation; MAT, mean annual temperature; PET, potential evapo-transpiration; Gs: indirect regional site index, based in the sapwood basal area per hectare.

\begin{tabular}{cccccc}
\hline Provenance & $\begin{array}{c}\text { Altitude } \\
(\mathrm{m})\end{array}$ & $\begin{array}{c}\text { MAP } \\
(\mathrm{mm})\end{array}$ & $\begin{array}{c}\text { MAT } \\
\left({ }^{\circ} \mathrm{C}\right)\end{array}$ & $\begin{array}{c}\text { PET } \\
(\mathrm{mm})\end{array}$ & $\begin{array}{c}\text { Gs } \\
\left(\mathrm{m}^{2} / \mathrm{ha}\right)\end{array}$ \\
\hline (V) Vilaflor & 1750 & 500 & 12 & 600 & 15.9 \\
(P) Pajonales & 1050 & 350 & 16 & 750 & 6.2 \\
\hline
\end{tabular}

the ontogenetic stage of every seedling was qualitatively assessed based on the occurrence and type of axillary shoots (see CHAMBEL et al., 2007 for details). Seedling height and diameter at the root collar was measured weekly and root silhouettes were drawn in an acetate sheet (only in $\mathrm{R}_{60}$ ).

We used a complete randomized design with periodical re-randomization. When the first taproot reached the bottom of a $R_{60}$ mini-rhizotron, all $R_{60}$ plants (4 per provenance) were harvested. A second harvest was done when the first taproot reached the bottom of a $R_{90}$ minirhizotron, and included all 6 plants per provenance grown in $R_{90}$ and the 6 plants per provenance grown in $\mathrm{C}_{200}$. With this protocol, we ensured that roots of plants grown in mini-rhizotrons did not suffer any restriction for growth. Harvest dates were JD 57 for $\mathrm{R}_{60}$ and JD 115 for $R_{90}$ and $C_{200}$. The plants were then partitioned into leaves, stems and roots for leaf morphology analysis and biomass assessments (PoORTER and NAGEL, 2000). Leafs of each plant were scanned and their census number and area were obtained using the ScionImage ${ }^{\circledR}$ software. For plants grown in mini-rhizotrons, main taproot, secondary and tertiary roots where further separated, scanned and image-analyzed to obtained root lengths $\left(\mathrm{R}_{1} \mathrm{~L}\right.$ and $\mathrm{R}_{2} \mathrm{~L}$, respectively). All plant parts were oven-
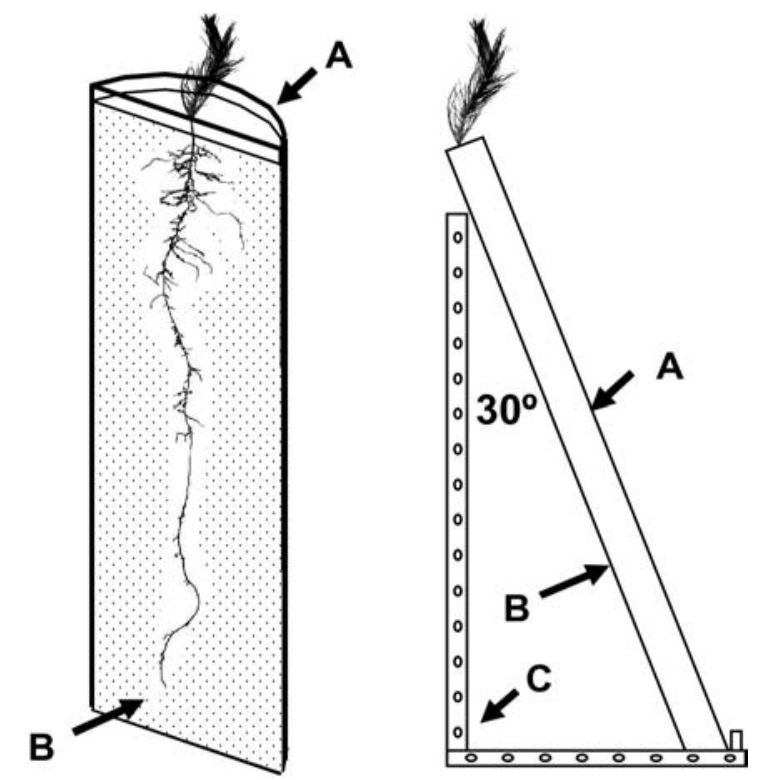

Figure 2. - Schematic representation of the mini-rhizotrons used in the experiment (A) and its disposition in a frame (C) to ensure that most roots grow attached to the transparent side (B). dried for 48 hours at $80^{\circ} \mathrm{C}$ and then weighted. Dry weights of leaves (LDW), stems (SDW), whole root systems $(\mathrm{RDW})$ and taproots $\left(\mathrm{R}_{1} \mathrm{DW}\right)$ were obtained and total dry weight (TDW) was calculated by summing up all former values. With this raw data we further calculated the derived variables whole root mass fraction (RMF), taproot mass fraction $\left(\mathrm{R}_{1} \mathrm{MF}\right)$, leaf mass fraction (LMF) and the ratio of total leaf area to total dry weight (LAR).

A classical plant growth analysis between the two harvests (JD 57 for $R_{60}$ and JD 115 for $R_{90}$ ) was performed for the plants in mini-rhizotrons, following the hypotheses of CAUSTON (1991). Differences between provenances for relative growth rate (RGR) and net assimilation rate (NAR) were checked using the means and confidence intervals calculated with the software available from (HuNT et al., 2002).

With the data obtained in the second harvest, a general linear model (GLM) was used to check for container and provenance effect and its interaction with the structure expressed by model [1].

$$
\mathrm{x}=\mu+\mathrm{c}+\mathrm{p}+\mathrm{c} \mathrm{xp}+\varepsilon
$$

where $\mathrm{x}$ is the observed value, $\mu$ is the general mean, $c$ is the effect of container type, $p$ is the provenance effect, $\mathrm{c} \times \mathrm{p}$ is the interaction between container and provenance and $\varepsilon$ is the experimental error (including within-provenance differences). Deviations from the requirements of ANOVA were assumable; hence we found no need to transform the variables. Means comparisons were based on Tukey's HSD test.

Seed size effect was non-significant (neither significant correlations with any of the studied variables nor significant effect as a covariate) and therefore we discarded to use this variable as a covariate in the ANOVAs.

\section{Results}

Seedling development and growth analysis in minirhizotrons

All seedlings remained at the juvenile stage during the experiment; i.e. exclusively primary needles and free growth pattern without developing axillary shoots, hence showing no morphological ontogenetic differences across provenances or container types. Considering both provenances together, the mean taproot length growth in mini-rhizotrons $\left(R_{60}\right.$ and $\left.R_{90}\right)$ was as high as one $\mathrm{cm} /$ day. By contrast, lateral roots that appeared between 


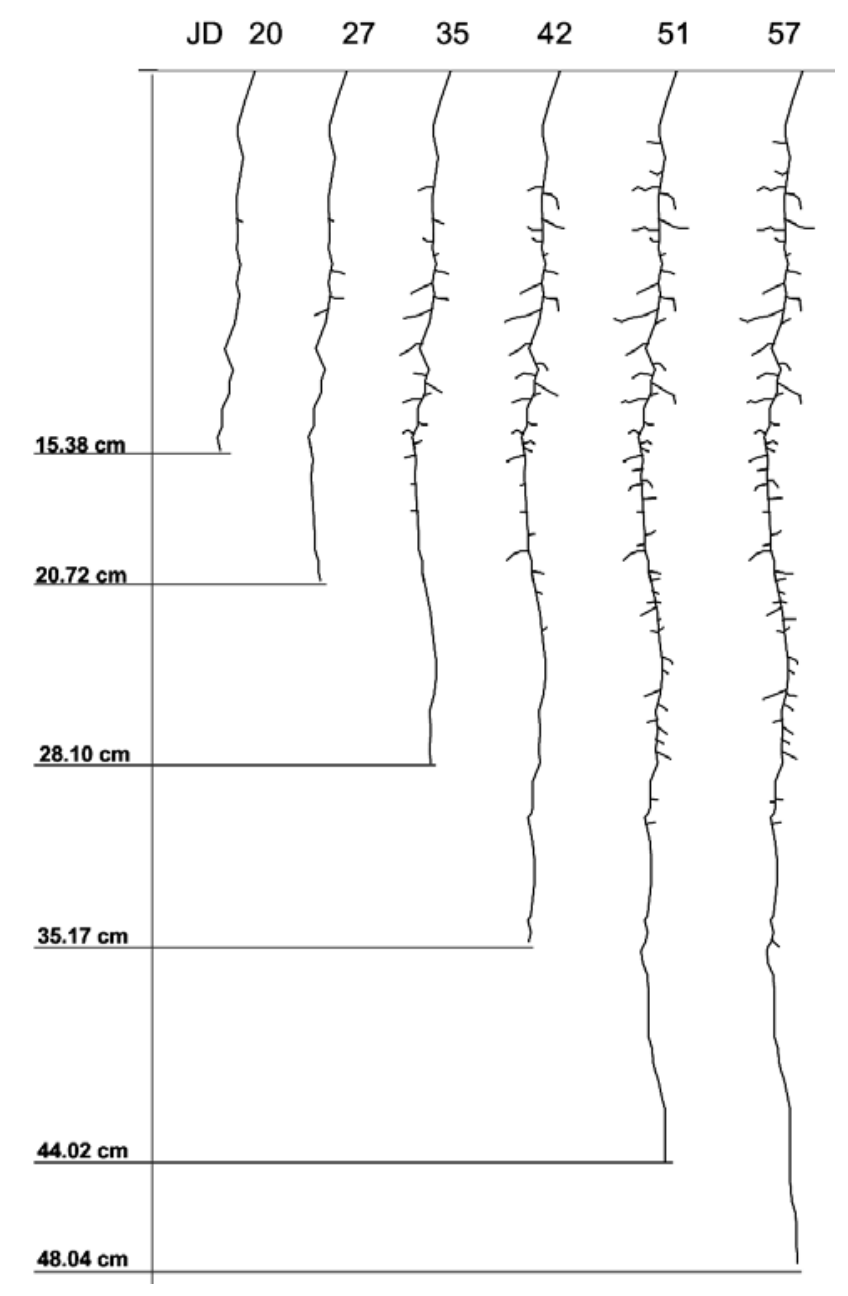

Figure 3. - Drawings of root development corresponding to one of the seedlings cultivated in mini-rhizotrons $R_{60}$ from JD 20 to JD 57. Both the fast root development and the predominance of the tap root seemed a general trait of the species.

JD 20 and 27 for most plants, grew at a much lower rate: between 2.7 and $8 \mathrm{~mm} /$ day. As a consequence, the root systems exhibited a strongly hierarchical structure (Figure 3) that remained until the end of the experiment, even when the proportion between the total length of lateral roots and taproots increased between the two harvests (from 0.58 to 1.33).

The number of leaves (stem units) per plant, height or diameter did not differ significantly between prove-
Table 2. - ANOVA table corresponding to model [1], at the second harvest (JD 115). for the response variables Root Mass Fraction (RMF), Taproot Mass Fraction ( $\left.\mathrm{R}_{1} \mathrm{MF}\right)$, Leaf Area Ratio (LAR) and Leaf Mass Fraction (LMF). P: provenance; C, container type.

\begin{tabular}{lllllll}
\hline & & df & SS & MS & $F$ & $\mathrm{~F}$ \\
\hline \multirow{4}{*}{ RMF } & $\mathrm{P}$ & 1 & 0.00621 & 0.00621 & 5.219 & 0.0340 \\
& $\mathrm{C}$ & 1 & 0.07526 & 0.07526 & 63.247 & 0.0000 \\
& $\mathrm{P} \times \mathrm{C}$ & 1 & 0.00583 & 0.00583 & 4.896 & 0.0394 \\
& Error & 19 & 0.02258 & 0.00119 & & \\
& $\mathrm{P}$ & 1 & 0.00957 & 0.00957 & 10.287 & 0.0046 \\
R1MF & $\mathrm{C}$ & 1 & 0.06905 & 0.06905 & 74.251 & 0.0000 \\
& $\mathrm{P} \times \mathrm{C}$ & 1 & 0.00417 & 0.00417 & 4.489 & 0.0475 \\
& Error & 19 & 0.01759 & 0.00093 & & \\
\hline \multirow{4}{*}{ LAR } & P & 1 & 0.00049 & 0.00049 & 4.491 & 0.0475 \\
& $\mathrm{C}$ & 1 & 0.00030 & 0.00030 & 2.744 & 0.1140 \\
& P $\times C$ & 1 & 0.00053 & 0.00053 & 4.862 & 0.0400 \\
& Error & 19 & 0.00208 & 0.00011 & & \\
\hline \multirow{4}{*}{ LMF } & P & 1 & 0.00228 & 0.00228 & 1.919 & 0.1820 \\
& $C$ & 1 & 0.03752 & 0.03752 & 31.530 & 0.0000 \\
& P $\times C$ & 1 & 0.00783 & 0.00783 & 6.531 & 0.0189 \\
& error & 19 & 0.02268 & 0.00119 & & \\
\hline
\end{tabular}

nances at any time of the experiment. Moreover, growth analysis between the two harvests yielded no significant differences between provenances neither for RGR (averaging $\left.0.021 \mathrm{day}^{-1}\right)$ nor for NAR $\left(0.26 \mathrm{mg} / \mathrm{cm}^{2}\right.$ day $)$.

\section{Container effect and provenance $x$ container interaction}

At the second harvest (JD 115) both provenance and container effects were highly significant for all variables except for LAR (with no significant container effect) and LMF (with no significant provenance effect) (Table 2). $R_{90}$ plants had a significantly higher root mass fraction than $\mathrm{C}_{200}$ plants, and an even higher difference for the taproot's biomass fraction (Table 3). As a consequence, leaf mass fraction was significantly higher for $\mathrm{C}_{200}$ plants. Otherwise, we did not find significant differences between the $R_{90}$ and the $C_{200}$ plants for total plant biomass (TDW), leaf biomass (LDW) or leaf area.

The interaction provenance $\mathrm{x}$ container was significant for the four variables analysed (Table 2). However, this interaction was more quantitative than qualitative (Fig. 4); i.e. there were no different provenance rankings between container types, but the difference between provenances was higher in the mini-rhizotrons for the four variables analysed (Figure 4 and Table 3). When

Table 3. - Least squares means derived from model [1] for container types and container $\mathrm{x}$ provenance combinations ( $P$, dry provenance Pajonales; $V$, wet provenance Vilaflor). Means with the same letter within each pair-wise comparison are not significantly different (Tukey's HSD, p > 0.05).

\begin{tabular}{lllll}
\hline $\begin{array}{l}\text { Container and container } x \\
\text { provenance combination }\end{array}$ & RMF & $\mathrm{R}_{1} \mathrm{MF}$ & $\mathrm{LAR}(\mathrm{cm} / \mathrm{mg})$ & $\mathrm{LMF}$ \\
\hline $\mathrm{C}_{200}$ & $0.193 \mathrm{~b}$ & $0.122 \mathrm{~b}$ & $0.065 \mathrm{a}$ & $0.595 \mathrm{a}$ \\
$\mathrm{R}_{90}$ & $0.297 \mathrm{a}$ & $0.224 \mathrm{a}$ & $0.074 \mathrm{a}$ & $0.529 \mathrm{~b}$ \\
\hline $\mathrm{C}_{200}-P$ & $0.203 \mathrm{a}$ & $0.136 \mathrm{a}$ & $0.063 \mathrm{a}$ & $0.599 \mathrm{a}$ \\
$\mathrm{C}_{700}-V$ & $0.183 \mathrm{a}$ & $0.107 \mathrm{a}$ & $0.066 \mathrm{a}$ & $0.592 \mathrm{a}$ \\
\hline $\mathrm{R}_{90}-P$ & $0.333 \mathrm{a}$ & $0.267 \mathrm{a}$ & $0.064 \mathrm{~b}$ & $0.489 \mathrm{~b}$ \\
$\mathrm{R}_{90}-V$ & $0.287 \mathrm{~b}$ & $0.202 \mathrm{~b}$ & $0.078 \mathrm{a}$ & $0.536 \mathrm{a}$ \\
\hline
\end{tabular}



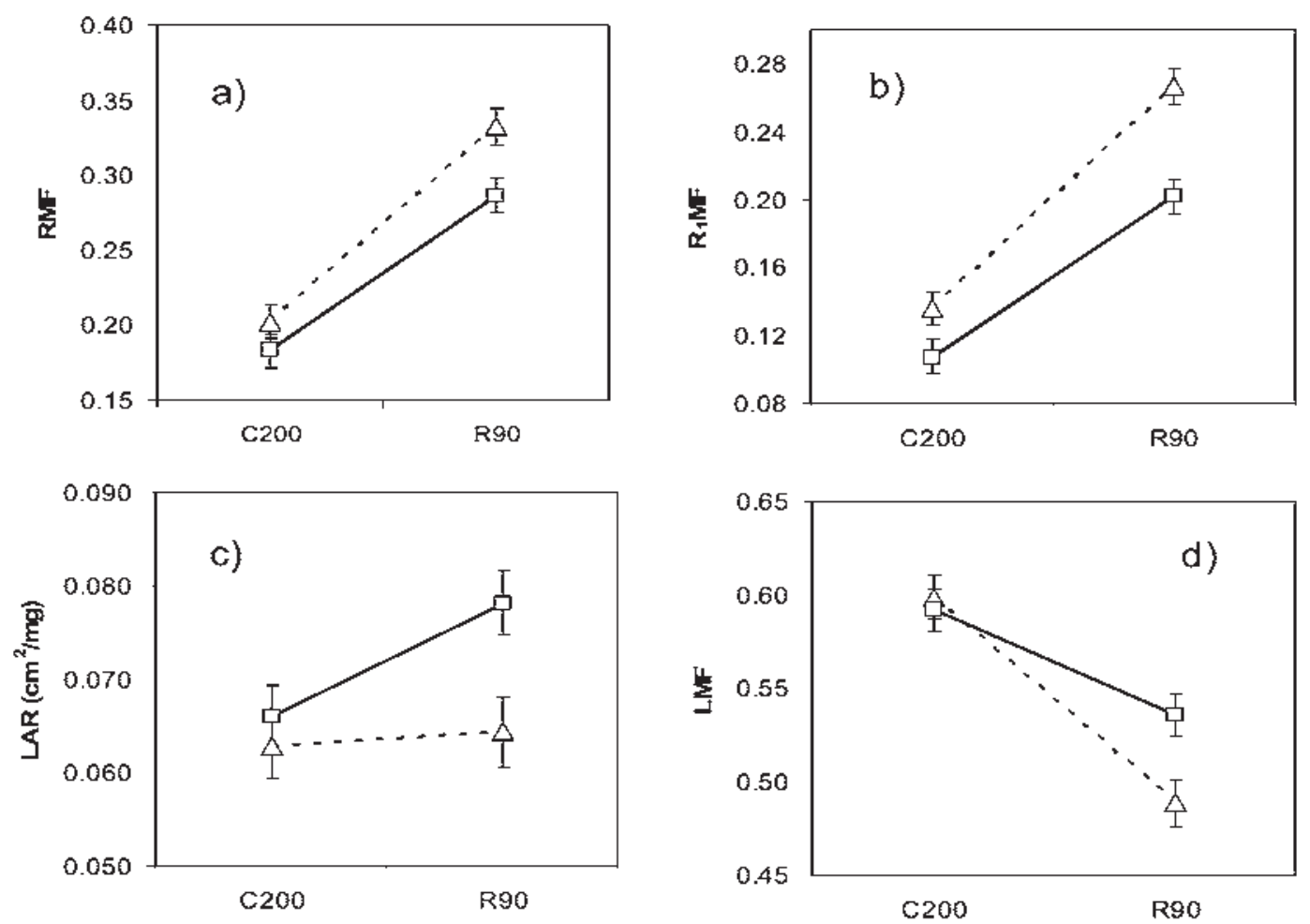

Figure 4. - Interaction plots of morphological traits between two Canary Island pine provenances (Pajonales $P$, triangles with dotted line and Vilaflor $V$, squares with continuous line) and container type $\left(\mathrm{C}_{200}\right.$, standard $200 \mathrm{cc}$ forest containers and $\mathrm{R}_{90}$ : mini-rhizotrons $90 \mathrm{~cm}$ deep) for plants harvested at 115 days (6 plants per combination). Data points represent means and bars correspond to standard errors. a) Root Mass Fraction b) Taproot Mass Fraction c) Leaf Area Ratio and d) Leaf Mass Fraction.

grown in $\mathrm{R}_{90}$, plants of the drier provenance, $P$, showed a significantly higher biomass allocated to the whole root system and to the taproot, and lower allocation to leaves, both on a leaf area or leaf biomass basis than plants from the wet $V$ provenance. By contrast, this difference was non-significant $(p>0.05)$ when plants were grown in $\mathrm{C}_{200}$.

\section{Discussion}

Until now, there was little or none experimental evidence of how the restriction for root growth may limit the expression of genetic differentiation in containerised tree seedlings. The functional processes underlying mechanical root restriction are multiple and complex: usually a main consequence of the reduced root growth is a subsequent decrease of shoot growth, because a restricted root system will supply insufficient water and nutrients to the shoot (see, for example FERREE et al., 1992; Nesmith and Duval, 1998). By contrast, in our experiment the growth of the whole plant was not severely limited by the type of container, judged from the lack of differences between types of containers in total plant biomass, leaf biomass and total leaf area. Hence, undesired size-related ontogenetic shifts that frequently obscure the interpretation of results (McConnaughay and Coleman, 1999; Goto et al., 2002) are kept to a minimum.

In coherence with optimal partitioning theory (BLOOM et al., 1985), the plants from the harsher provenance $(P)$ had higher biomass allocation to the whole root system and especially to the taproot and supported lower leaf biomass and leaf area than the plants of provenance $(V)$, from a site with more favourable growth conditions. Similar differentiation in allocation patterns between provenances has been found also in Maritime pine (Aranda, pers. com.), Scots pine (OHLson, 1999) and poplar (ZHANG et al., 2005). Moreover, the similar performance of both provenances in terms of relative growth rate, number of stem units and ontogeny indicates that at the time scale of our experiment, root/shoot allometry constitutes the main source of developmental divergence. In addition, both the lack of correlation of seedling morphometry with seed size and the increase of provenance differentiation between the first and second harvest lead us to discard maternal effects as a cause of concern for the purposes of this experiment.

Confirming our hypothesis, the allometric differentiation between provenances was absent or less marked in $\mathrm{C}_{200}$ containers, resulting in a significant container $\mathrm{x}$ provenance interaction. This result does support the concerns on container size effects on the early performance of forest trees (APHALO and RIKALA, 2003; THIFFAULT, 2004; SoUTH et al., 2005). In fact our results indicate that container effects might restrict and rule out genetic differences in biomass allocation. By contrast, pot size has been considered a minor effect when comparing more dramatic differences caused by nutrient concentration or $\mathrm{CO}_{2}$ levels in different plants (BERNTSON et al., 1993). 
If it could be argued that a limited expression of the genetic differences concerning seedling biomass allocation does not necessarily imply a wrong genotype ranking in early testing (in our study, the interaction provenance $x$ container was quantitative, not qualitative), the low juvenile-adult correlations frequently found in retrospective genetic tests of forest trees (see, for example LASCOUX et al., 1993; SONESSON et al., 2001; ZAS et al., 2004) could be partially due to root restriction. Before emergent methods avoiding the use of containers, such as polyethylene-glycol based hydroponic cultivation (HARFOUCHE, 2003) are implemented for wide, practical use, the use of bigger containers compatible with each experiment's practical limitations seems highly recommendable. The expected increase in allometric divergence should allow reducing the number of plants harvested for attaining the same precision in the comparisons, therefore minimising time and costs.

\section{Acknowledgements}

This research was funded by the Island Administrations (Cabildos) of Tenerife and Gran Canaria. Thanks to R. CHAMBel for English editing of the manuscript and to E. PÉREZ for her initiative and technical assistance. J. Climent is granted by a Ramon y Cajal fellowship of the Spanish Ministry for Education and Science.

\section{References}

APHALO, P. and R. RIKALA (2003): Field performance of silver-birch planting-stock grown at different spacing and in containers of different volume. New Forests 25: 93-108.

Beaulieu, J., M. Perron and J. Bousquet (2004): Multivariate patterns of adaptive genetic variation and seed source transfer in Picea mariana. Canadian Journal of Forest Research 34: 531-545.

BeEson, R. C. (1993): Benefits of progressively increasing container size during nursery production depend on fertilizer regime and species. Journal of the American Society for Horticultural Science 118: 752-756.

Berntson, G. M., K. D. M. McConnaughay and F. A. BazZAZ (1993): Elevated $\mathrm{CO}_{2}$ alters deployment of roots in "small" growth containers. Oecologia 94: 558-564.

Blanco, A., M. Castroviejo, J. L. Fraile, J. M. Gandullo, L. A. Muñoz and O. SANChez (1989): Estudio ecológico del Pino canario. In: Serie Técnica, pp. 199. Madrid: ICONA.

Bloom, A. J., F. S. Chapin and H. A. Mooney (1985): Resource limitation in plants - an economic analogy. Annual Review of Ecology \& Systematics 16: 363-392.

CAUston, D. R. (1991): Plant-growth analysis - the variability of relative growth-rate within a sample. Annals of Botany 67: 137-144.

Ceballos, L. and F. ORTuÑo (1951): Vegetación y flora forestal de las Canarias Occidentales, pp. 465. Madrid: IFIE.

Climent, J., M. R. Chambel, R. López, S. Mutke, R. Alía and L. GIL (2006): Population divergence for heteroblasty in the Canary Islands pine (Pinus canariensis, Pinaceae). American Journal of Botany 93: 840-848.

Climent, J., L. Gil, E. PÉrez and J. Pardos (2002): Efecto de la procedencia en la supervivencia de plántulas de Pinus canariensis Sm. en medio árido. Investigación Agraria: Sistemas y Recursos Forestales 11: 171-180.
Climent, J., R. Tapias, J. A. Pardos and L. Gil (2004): Fire adaptations in the Canary Islands pine (Pinus canariensis). Plant Ecology 171: 185-196.

Chambel, M. R., J. Climent and R. AlíA (2007): Divergence among species and populations of Mediterranean pines in biomass allocation of seedlings grown under two watering regimes. Annals of Forest Science 64: 87-97.

Danjon, F., D. Bert, C. Godin and P. TRichet (1999): Structural root architecture of 5-year-old Pinus pinaster measured by 3D digitising and analysed with AMAPmod. Plant and Soil 217: 49-63.

DANJon, F., T. FourCaud and D. BERT (2005): Root architecture and wind-firmness of mature Pinus pinaster. New Phytologist 168: 387-400.

FerRee, D. C., S. C. Myers and J. R. Schupp (1992): Root pruning and root restriction of fruit trees-current review. Acta Horticulturae (ISHS) 322: 153-166.

GLIMSKAR, A. (2000): Estimates of root system topology of five plant species grown at steady-state nutrition. Plant and Soil 227: 249-256.

Gomez, A., S. C. Gonzalez-Martinez, C. Collada, J. CliMENT and L. GIL (2003): Complex population genetic structure in the endemic Canary Island pine revealed using chloroplast microsatellite markers. Theoretical and Applied Genetics 107: 1123-1131.

Goto, T., T. MAtsuno, Y. YoshidA and Y. Kageyama (2002): Photosynthetic, evapotranspiratory and leaf morphological properties of chrysanthemum grown under root restriction as affected by fertirrigation frequency. Journal of the Japanese Society for Horticultural Science 71: 277-283.

GuerRero-CAmpo, J. and A. H. FitTer (2001): Relationships between root characteristics and seed size in two contrasting floras. Acta Oecologica-International Journal of Ecology 22: 77-85.

HARFOUCHE, A. (2003): Retrospective early test for adult vigor of Pinus pinaster families grown under two water regimes. Implications for early selection. Annals of Forest Science 60: 539-547.

Hunt, R., D. R. Causton, B. Shipley and A. P. Askew (2002): A modern tool for classical plant growth analysis. Annals of Botany 90: 485-488.

KEELEY, J. and P. ZEDLER (1998): Life history evolution in pines. In: Biogeography of Pinus, pp. 219-242. Edited by D. M. RichaRdSON. Cambridge University Press.

KeRKHOFF, A. J. and B. J. ENQUist (2006): Ecosystem allometry: the scaling of nutrient stocks and primary productivity across plant communities. Ecol Lett. 9: 419-427.

Lascoux, D. M., A. Kremer and I. Dormling (1993): Growth and phenology of 1-year-old maritime pine (Pinus pinaster) seedlings under continuous light Implications for early selection. Canadian Journal of Forest Research 23: 1325-1336.

McConnaughay, K. D. M. and J. S. Coleman (1999): Biomass allocation in plants: ontogeny or optimality? A test along three resource gradients. Ecology 80: 2581-2593.

NeSMith, D. S. and J. R. Duval (1998): The effect of container size. Horttechnology. 8.

NIKLAS, K. J. (2004): Plant allometry: is there a grand unifying theory? Biol Rev. 79: 871-889.

NIKLAS, K. J. and B. J. ENQUIST (2002): On the vegetative biomass partitioning of seed plant leaves, stems, and roots. Am Nat. 159: 482-497.

OHLson, M. (1999): Differentiation in adaptive traits between neighbouring bog and mineral soil populations of Scots pine (Pinus sylvestris). Ecography 22: 178-182. 
PAZ, H. (2003): Root/shoot allocation and root architecture in seedlings: Variation among forest sites, microhabitats, and ecological groups. Biotropica 35: 318-332.

Poorter, H. and O. NAGEL (2000): The role of biomass allocation in the growth response of plants to different levels of light, $\mathrm{CO}_{2}$, nutrients and water: a quantitative review. Australian Journal Plant Physiology 27: 595-607.

Retzlaff, W. A., J. A. Handest, D. M. O’Malley, S. E. McKeAND and M. A. TopA (2001): Whole-tree biomass and carbon allocation of juvenile trees of loblolly pine (Pinus taeda): influence of genetics and fertilization. Canadian Journal of Forest Research 31: 960-970.

RUNE, G. (2003): Slits in container wall improve root structure and stem straightness of outplanted Scots pine seedlings. Silva Fennica 37: 333-342.

Sonesson, J., G. JANSSON and G. ERIKSSON (2001): Retrospective genetic tests of Pinus sylvestris L. in growth chambers with two irrigation regimes and two temperatures. Scand J Forest Res. 16: 21-29.
South, D. B., S. W. Harris, J. P. Barnett, M. J. Hainds and D. H. GJERSTAD (2005): Effect of container type and seedling size on survival and early height growth of Pinus palustris seedlings in Alabama, USA. Forest Ecology and Management 204: 385-398.

Thiffault, N. (2004): Stock type in intensive silviculture: A (short) discussion about roots and size. Forestry Chronicle 80: 463-468.

WANG, E. L. and C. J. SMith (2004): Modelling the growth and water uptake function of plant root systems: a review. Australian Journal of Agricultural Research 55: 501-523.

Zas, R., E. Merlo and J. Fernandez-Lopez (2004): Juvenile - Mature genetic correlations in Pinus pinaster Ait. under different nutrient $\mathrm{x}$ water regimes. Silvae Genet. 53: 124-129.

Zhang, X., N. Wu and C. Li (2005): Physiological and growth responses of Populus davidiana ecotypes to different soil water contents. Journal of Arid Environments 60: $567-579$.

\title{
Spatial Genetic Structure Within Two Contrasting Stands of Scots Pine (Pinus sylvestris L.)
}

\author{
By I. J. Chybicki ${ }^{\left.1),{ }^{*}\right)}$, A. Dzialuk ${ }^{1)}$, M. Trojankiewicz ${ }^{1)}$, M. Slawski $^{2)}$ and J. BurczyK ${ }^{1)}$
}

(Received $3^{\text {rd }}$ January 2007)

\begin{abstract}
When considering neutral nuclear markers, genetic differentiation of Scots pine (Pinus sylvestris L.) populations is known to be low. The homogeneity arises particularly as an effect of common ancestry in a recent evolutionary history as well as an extensive gene flow, especially through pollen. However, within populations several other forces may shape the spatial distribution of genetic variation, including establishment history, environmental and silvicultural selection. These local forces are known to produce non-random spatial patterns of genetic variation, however little is known on fine-scale spatial genetic structure of Scots pine. In this study, two stands of this species with different establishment histories, selected within one larger population located in northern Poland were genotyped and analysed for genetic variation and within-stand spatial genetic structure. Results revealed no differences in genetic variation, although stands are separated about $60 \mathrm{~km}$, suggesting that the two populations share a common genet-

1) Department of Genetics, Institute of Biology and Environmental Protection, Kazimierz Wielki University of Bydgoszcz, Bydgoszcz 85-064, Poland.

2) Department of Forest Protection and Ecology, Faculty of Forestry, Warsaw Agricultural University, Warsaw 02-787, Poland.

*) Communicating author. Telephone: +48-52-3419281. Fax: +4852-3608391. E-mail: igorchy@ukw.edu.pl
\end{abstract}

ic pool. The spatial genetic structure in both stands was found to be slightly different and was attributed to differences in the mode of populations' establishments. Finally, results confirmed that gene flow in Scots pine is extensive, causing genetic homogeneity within a single population.

Key words: genetic structure, spatial autocorrelation, relatedness coefficient, forest management, colonization, Scots pine.

\section{Introduction}

When considering neutral nuclear markers, the genetic variation of Scots pine (Pinus sylvestris L.) is generally high and accumulated mainly within populations, while genetic differences among populations are fairly small (PRUS-GLOWACKI et al., 1993; GONCHARENKO et al., 1994b; DvORNYK, 2001). Only marginal populations, especially from Iberian Peninsula, reveal significant genetic divergence from the rest of European populations (PRUs-GLOWACKI and STEPHAN, 1994; DvorNYK et al., 2002). The homogeneous nature of a macro-geographical variation might arise primarily as an effect of a common ancestry in a recent evolutionary history of the species (GULLBERG et al., 1985). Because pollen of Scots pine has a great mobility potential (LINDGREN et al., 1995), the homogeneity could be easily maintained over distances. However, at a local scale many other fac- 